\title{
Toxicity of Subacute Oral Zinc Oxide Nanoparticles on Testes and Prostate of Adult Albino Rats and Role of Recovery
}

Dalia I.A. Mesallam', Raghda H. Deraz', Sara M. Abdel Aal² and Samah M. Ahmed²*

${ }^{*}$ Correspondence: dr_samah_m@yahoo.com

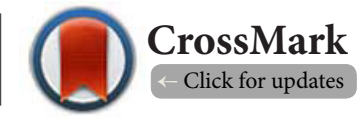

${ }^{1}$ Forensic Medicine \& Clinical Toxicology, Faculty of Medicine, Zagazig University, Zagazig, Egypt. ${ }^{2}$ Histology \& Cell Biology Departments, Faculty of Medicine, Zagazig University, Zagazig, Egypt.

\begin{abstract}
Background: Zinc oxide nanoparticles (ZnO NPs) have immense potential and application in various types of cosmetic products and health care sectors. They have attractive properties, and attracted great interest worldwide. Yet despite its potentially interesting beneficial effects, it has been proven that they can be also cytotoxic and genotoxic for multiple types of human cells, especially the reproductive system.

Aim of the work: Our study aimed to detect the effect of oral subacute $\mathrm{ZnO}$ NPs on the testes and prostate of adult albino rats and the role of recovery.

Materials and Methods: Forty adult male albino rats were divided into three groups; control (positive and negative), ZnONP-treated group for four weeks and a similarly treated group left for supposed recovery improvement testing two weeks after cessation of $\mathrm{ZnONP}$ administration. All rats were examined for serum oxidative stress markers, testicular and prostatic tissue inflammatory cytokines, DNA fragmentation, and extended histopthological evaluation.Histological study was performed using hematoxylin and eosin and Masson trichrome stains. Immunohistochemical expression for iNOs was performed. Morphometric and statistical analysis were also performed.

Results: Statistically significant difference in the oxidative stress and inflammatory markers and DNA shearing and aggressive histopathological testicular and prostatic changes were also detected in ZnONPtreated group as compared to the control and the follow up group that showed significant improvement.. Immunohistochemical examination of testicular and prostatic sections of $\mathrm{ZnONP}$ - treated group revealed highly statistically significant increase in the mean area percent of iNOs immunoreactions which significantly decreased in follow up groups.

Conclusion: ZnONPs have detrimental male reproductive effects that can be controlled by limiting the exposure to such products.
\end{abstract}

Keywords: Zinc oxide nanoparticles, toxicity, testes, prostate, DNA damage

\section{Introduction}

ZnO NPs have many applications in various types of cosmetic products and health care sectors. They are found in many products such as sunscreens, food additives, pigments, rubber manufacture, and electronic materials. So, it was necessary to assess their safety as well as toxic aspects $[\mathbf{1 , 2}]$.
In spite of the remarkable advantages of NPs in medicine and industry, there have been raised evidence about their potential adverse effects in the living organisms. Unintentional exposure of human to NPs was reported, mainly at workplaces and consumers of engineered NPs-based products that has been reported to enter human body through lungs, gastrointestinal tract, skin, 
and subsequently reach systemic circulation and deposited in many organs and lead to various adverse effects [3].

Safety evaluation of nanostructures is an emerging discipline called nanotoxicology. Nanoparticles can accumulate and persist in the organism for decades [4]. ZnO NPs are utilized in various consumer products, so many studies have shown their toxic effects in several experimental models, as cell lines, bacteria, algae, plants, and fish. principally, in vivo study is considered necessary to investigate their toxic effect in biological systems [5].

Spermatogenesis is a biological process, including proliferation and differentiation of germ cells leading to the production of spermatozoa. Survival of such process is dependent upon the presence of hormones, reactions and dynamic connections between Sertoli cells and germ cells [6]. Sertoli cells provide an encouraging environment for the growth and differentiation of germ cells by secreting hormones, as paracrine factors play a role in the growth and differentiation of cells, and nutritional factors. This complex hormonal configuration in testis has made it anideal target for the effectiveness of many toxins [7].

A variety of studies have shown that most of nanoparticles have toxic effect on male germ cells [8]. They indicated the accumulation of nanoparticles in tissues, like rat nervous and testicular tissues as have the capability to cross testes and blood-brain barrier [9]. Moreover, Zn molecule accumulates in the testis in similar amounts as that in the kidney and liver [10]. Adequate zinc intake is essential for maintaining the optimal testicular function [11].

ZnONPs have different physicochemical properties compared to zinc $(\mathrm{ZnO})$ which can affectthe bioactivity and toxicity of ZnONPs [12]. It is suggested that the size of nanoparticles and its surface area greatly increase their ability to produce reactive oxygen species (ROS) hence their specific cytotoxicity [13].

\section{Materials and Methods}

Preparation of Zinc Oxide nanoparticles (ZnO NPs)

$\mathrm{ZnO}$ Nano powder characterized with $<100 \mathrm{~nm}$ particle size, purity $\geq 99.5 \%$ trace metals basis and molecular weight equals $81.39 \mathrm{~g} / \mathrm{mol}$ was purchased from Sigma, Cairo, Egypt. Its Chemical Abstract Service registration Number (CAS No) is 1314-13-2. It is a white odourless, fine powder manufactured by ( Sigma -Aldrich chemical company). It was dissolved in distilled water obtained from SEDICO Company, Egypt.

\section{Zinc Oxide Nanoparticle characterization}

For studying zinc oxide nanoparticles size and morphology, the aqueous dispersion of the nanoparticles was dropped cast onto a carbon-coated copper grid. This grid was air dried at room temperature [1] andvisualized using (Transmission Electron Microscope) (JEOL JEM-2100, Jeol Ltd, Tokyo, Japan) at Electron Microscope Research Unit, Faculty of Agriculture, ALmansora University, Egypt.

\section{Animals and experimental design}

Forty adult male albino rats weighing (150-210 g) were obtained from the animal house, Faculty of Medicine, Zagazig University. Rats were housed and maintained under standardized environmental conditions. Principles of laboratory animal care followed recommendations of the National Institutes of Health Guide for Care and Use of Laboratory Animals [14], and Zagazig University, Faculty of Medicine Institutional animal house and the study was conducted in accordance with the international guidelines for animal research and after the approval of the Institutional Review Board (IRB) on animal research at Faculty of Medicine, Zagazig University, Egypt.

Rats were randomly divided into three groups; Group I (control group): contained twenty rats further subdivided into two equal subgroups 10 rats each: subgroup la (negative control group): this group received no treatment to measure the basic parameters. Subgroup Ib (vehicle control group): each rat received $1 \mathrm{ml} /$ day distilled water (Solvent of ZnO NPs) orally by gavage. Group II (ZnONPs treated group): contains 10 rats each one of this group received $422 \mathrm{mg} / \mathrm{kg} /$ day for 4 weeks, $\mathrm{ZnO}$ NPs dissolved in distilled water were dispersed by ultrasonic vibration for $15 \mathrm{~min}$. This dose represents $1 / 20$ of oral $\mathrm{LD}_{50}$ of Zinc oxide nanoparticles in rats $(8437 \mathrm{mg} / \mathrm{kg})$ (Material Safety Data Sheet acc. to OSHA and ANSI) [15]. Group III (follow up /recovery group): contains 10 rats each, rats were treated withZnO NPs as group II then left without treatment for 2 weeks (wash out period for probable improvement) [16].

At the end of the experiment, rats from all groups were anaesthetized through intra-peritoneal injection of pentobarbital50 mg/kg. Blood samples were collected from retro-orbital plexus of each rat according to the method described by [17]. Blood was left for spontaneous coagulation to separate the serum. It was further centrifuged for 15 minutes and kept at $-80^{\circ} \mathrm{C}$ for later biochemical investigations. The testes and prostate were excised from all rats to be used for further biochemical and histological assessment.

\section{Biochemical Studies}

The following biochemical parameters were estimated in Biochemistry Department, Faculty of Medicine, Zagazig University.

\section{Measurement of oxidative stress biomarkers}

The serum MDA was assayed colorimetrically according to the method of [18]. Reduced glutathione (GSH) content, antioxidant enzymescatalase (CAT) and superoxide dismutase (SOD) using Biodiagnostic kits (Biodiagnostic, Giza, Egypt) according to methods described by $[\mathbf{1 9 , 2 0 ]}$ respectively.

\section{Testicular and prostatic tissue cytokines}

Tissue pro-inflammatory cytokine (TNF-a) was assayed using enzyme-linked immunosorbent assay (ELISA) using a microplate reader (Spectra III Classic, Tecan, Salzburg, Austria) as previously described by [21]. The anti-inflammatory (IL-4 cytokine was assayed, as well, using RayBio rat IL-4 ELISA 
kit (Catalog number ELR-IL4-CL) according to the manual instructions.

\section{DNA fragmentation (qualitative) analysis}

For DNA laddering, genomic DNA samples were extracted from $-80^{\circ} \mathrm{C}$ preserved testicular and prostatic samples from rats of all groups. Genomic DNA samples were electrophoresed on (1.5\% agarose/ethidium bromide gel) for DNA ladder detection using commercially available G-spin ${ }^{\text {TM }}$ total DNA extraction kit (iNtRON Biotechnology, Seongnam-Si, Gyeonggi-do, South Korea) according to [22].

\section{Histological and Immunohistochemical Studies Histological study}

The testes and prostate from each animal were dissected and the specimens were immersed in $10 \%$ formol saline for $48 \mathrm{~h}$ to be processed to get $5 \mu \mathrm{m}$-thick paraffin sections and stained with hematoxylin and eosin to display the histological details andwith Masson trichrome (MT) to demonstrate the collagen fibers according to [23].

\section{Immunohistochemical study}

Immunohistochemical reaction was performed using avidinbiotin peroxidase complex (Dakocompany, Wiesentheid/ Bavaria, Germany, Biotin Blocking System, Code X0590) method following the manufacturer's instructions. Four $\mu \mathrm{m}$ serial sections of paraffin-embedded specimens were deparaffinized on positively charged slides. The sections were incubated in $0.1 \%$ hydrogen peroxide for ten minutes to block the endogenous peroxidase activity and then incubated with the primary antibody. The primary antibody used for iNOs was ready-to-use rabbit polyclonal antibody (CAT-No. RB-9243-R7). The slides were incubated with the ( secondary anti-rabbit antibody versal kits) (Zymed laboratories) diluted 1:200 for 30 minutes. Staining was completed by incubation with chromogen, called diamiobenzidine (DAB). Mayer's hematoxylin was used as a counterstain [24].

\section{Histo-Morphometric Analysis}

Sections stained with Masson trichrome and iNOsimmunoreaction were morphometrically analysed using Leica Qwin 500 Image Analyzer Computer System (England) at Pathology Department, Faculty of Dentistry, Cairo University. Area (\%) of collagen fibers in MTstained sections and iNOs immuneoreaction was measured. All the parameters were measured for the randomly chosen five fields per section in total five sections from 8 rats in each group.

\section{Statistical Analysis}

Data from all groups were expressed as mean \pm standard deviation $(X \pm S D)$. The data obtained were subjected to SPSS program, version 16 (Chicago, USA). Statistically significant difference was determined by one-way analysis of variance (ANOVA) test, followed by the post hoc test for multiple com- parisons between different groups. The probability values $(P)$ less than 0.05 were consideredstatistically significant.

\section{Results}

Characterization of Zinc Oxide Nanoparticles

Transmission Electron Microscope examination of zinc oxide nanoparticles revealed that their sizes were less than 100 nm (Figure 1).

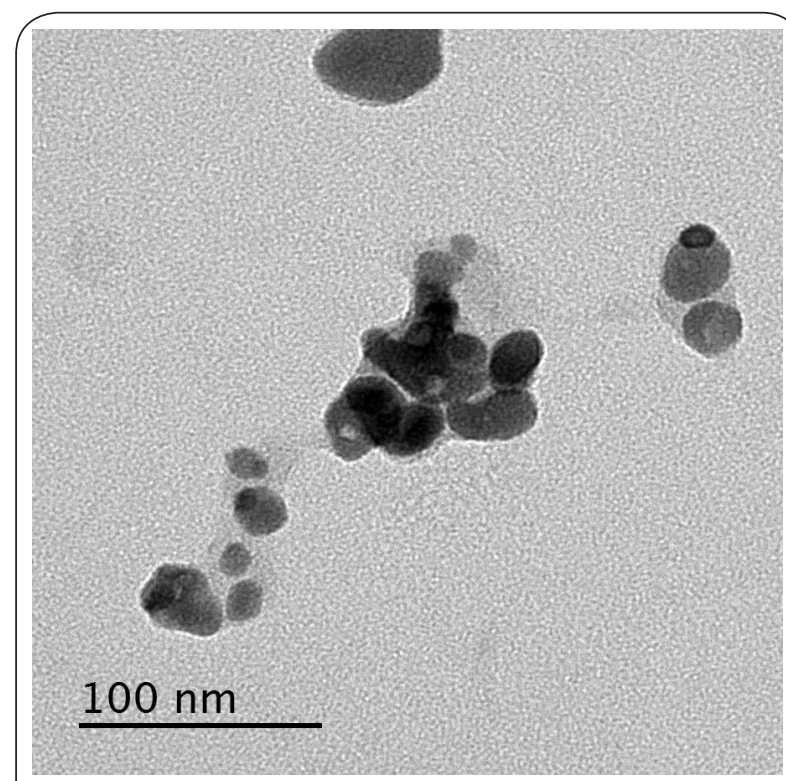

Figure 1. An electron micrograph showing $\mathrm{ZnO}$ NPs of diameter less than $100 \mathrm{~nm}$.

\section{Biochemical Studies}

On comparison of serum oxidative stress biomarker, and tissue (testicular and prostatic) cytokines content results ofboth negative and positive control groups, there was no significant difference $(P>0.05)$. So, the negative controlgroup was used for comparison with the other treated groups.

\section{Serum Oxidative stress biomarkers}

Administration of Zinc oxide nanoparticles resulted in a significant elevation in serum level of lipid peroxidation product (MDA) that associated with a significant reduction of the antioxidants (GSH, CAT and SOD activities) found inthe 4th week evaluation. Cessation of ZnO NPs for two weeks significantly suppressed of serum (MDA) and reversed the reduction in the (GSH) and antioxidant enzyme activities at the $6^{\text {th }}$ week evaluation (Table 1).

\section{Tissue cytokine (TNF- $\alpha$ and IL-4) contents}

Zinc oxide nanoparticles administration significantly elevated pro-inflammatory (TNF-a) cytokines and decreased the antiinflammatory IL-4 contents in testicular and prostatic tissues. While on cessation of ZnO NPs in follow up group, there was 
a marked decline in testicular and prostatic tissues TNF- $\alpha$ and a rise in testicular and prostatic tissues IL-4 contents (Table 2). DNA fragmentation (qualitative) analysis (DNA laddering) : DNA ladder assay revealed no appreciable fragmentation of DNA neither in the testicular nor prostatic tissue in both control subgroups. Meanwhile, DNA fragmentation (sever shearing of DNA) was detected in testes and prostates of $\mathrm{ZnO}$ NPs-treated rats and wasnoticed to be milder in the recovery group rats (group III) (Figures 2 and $\mathbf{3}$ ).

Table 1. Serum oxidative stress biomarkers of the studies groups.

\begin{tabular}{c|c|c|c}
\hline $\begin{array}{c}\text { Groups } \\
\text { parameters }\end{array}$ & $\begin{array}{c}\text { control } \\
\text { (Ia) }\end{array}$ & $\begin{array}{c}\text { ZnO NP } \\
\text { (II) }\end{array}$ & $\begin{array}{c}\text { Follow up } \\
\text { (II) }\end{array}$ \\
\hline $\begin{array}{c}\mathrm{MDA} \\
(\mathrm{nmol} / \mathrm{ml})\end{array}$ & $0.32 \pm 0.018$ & $7.3 \pm 2.41^{\mathrm{a}}$ & $2.83 \pm 1.4^{\mathrm{b}}$ \\
\hline $\begin{array}{c}\mathrm{GSH} \\
(\mathrm{nmol} / \mathrm{ml})\end{array}$ & $25.8 \pm 1.62$ & $14.3 \pm 2.16^{\mathrm{a}}$ & $21.5 \pm 2.32^{\mathrm{b}}$ \\
\hline $\begin{array}{c}\mathrm{CAT} \\
(\mathrm{U} / \mathrm{ml})\end{array}$ & $19.5 \pm 1.96$ & $4.83 \pm 2^{\mathrm{a}}$ & $17.8 \pm 4.2^{\mathrm{b}}$ \\
\hline $\begin{array}{c}\mathrm{SOD} \\
(\mathrm{U} / \mathrm{ml})\end{array}$ & $15 \pm 1.25$ & $8.91 \pm 2.4^{\mathrm{a}}$ & $13 \pm 2.6^{\mathrm{b}}$ \\
\hline \hline
\end{tabular}

Results values are expressed as mean \pm standard deviation (SD) of $\mathrm{n}=10$ rats/group

${ }^{a}$ Significant as compared with the untreated and vehicle control groups, $\mathrm{P}<0.05$

${ }^{b}$ Significant as compared with the $\mathrm{ZnO}$ NPs group, $\mathrm{P}<0.05$

Table 2. Testicular and prostatic tissues TNF- $\alpha$ and IL-4 of the studied.

\begin{tabular}{l|l|c|c}
\hline \multicolumn{1}{c|}{ Groups } & \multicolumn{1}{c|}{$\begin{array}{c}\text { control } \\
\text { (Ia) }\end{array}$} & $\begin{array}{c}\text { ZnO NP } \\
\text { (II) }\end{array}$ & $\begin{array}{c}\text { Follow up } \\
\text { (III) }\end{array}$ \\
\hline $\begin{array}{l}\text { Testis TNF- } \alpha \\
\text { (pg/mg protein) }\end{array}$ & $6.94 \pm 0.9$ & $14.7 \pm 3.3^{\mathrm{a}}$ & $7.9 \pm 1.3^{\mathrm{b}}$ \\
\hline $\begin{array}{l}\text { Prostate TNF- } \alpha \\
\text { (pg/mg protein) }\end{array}$ & $6.8 \pm 0.6$ & $15.3 \pm 1.83^{\mathrm{a}}$ & $7.6 \pm 1.5^{\mathrm{b}}$ \\
\hline $\begin{array}{l}\text { Testis IL-4 } \\
\text { (pg/mg protein }\end{array}$ & $22.1 \pm 1.1$ & $7.1 \pm 1.85^{\mathrm{a}}$ & $21.6 \pm 1.71^{\mathrm{b}}$ \\
\hline $\begin{array}{c}\text { Prostate I-4 } \\
(\mathrm{pg} / \mathrm{mg} \text { protein) }\end{array}$ & $20.7 \pm 1.34$ & $7.27 \pm 2.03^{\mathrm{a}}$ & $19.3 \pm 1.77^{\mathrm{b}}$ \\
\hline \hline
\end{tabular}

Results values are expressed as mean \pm standard deviation (SD) of $\mathrm{n}=10$ rats/group

aSignificant as compared with the untreated and vehicle control groups, $\mathrm{P}<0.05$.

${ }^{\mathrm{b}}$ Significant as compared with the $\mathrm{ZnO}$ NPs group, $\mathrm{P}<0.05$.

\section{Histological and Immunohistochemical Results}

No histological differences were noticed between the untreated control and vehicle control groups. So, we considered them as one group.

\section{Testis}

\section{Histological findings}

H\&Estained sections from the testes ofcontrol group revealed

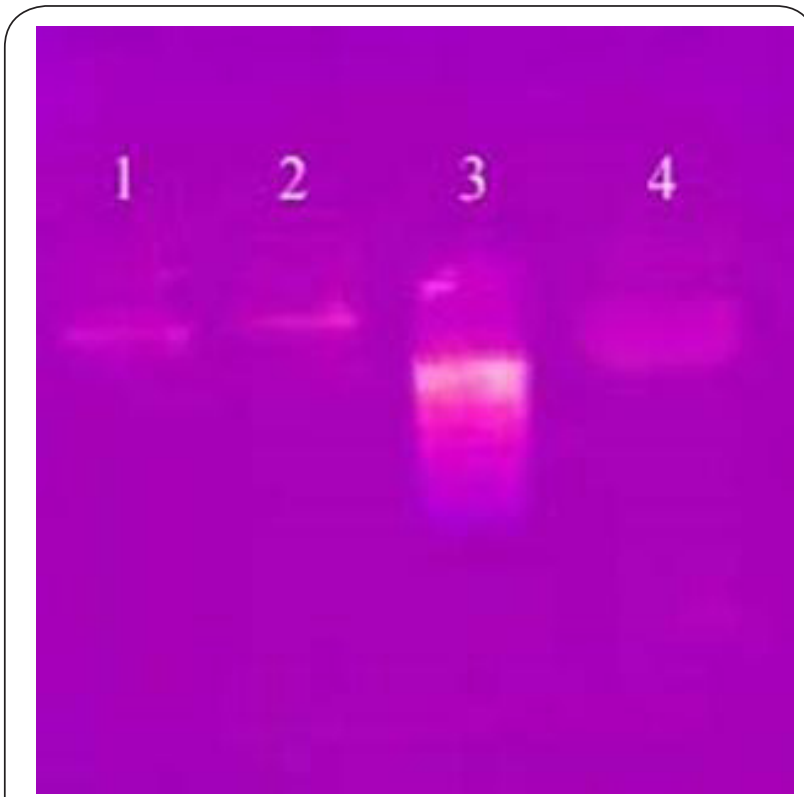

Figure 2. Agarose gel electrophoresis of DNA isolated from adult male albino rat testes (Figure 2 ) and prostate (Figure 3) of studied groups. Lane 1, 2: normal DNA band of (negative and vehicle)control groups. Lane 3: showing advanced shearing of DNA in $\mathrm{ZnO}$ NPs treated group. Lane 4: showing mild DNA fragmentation in follow up group.

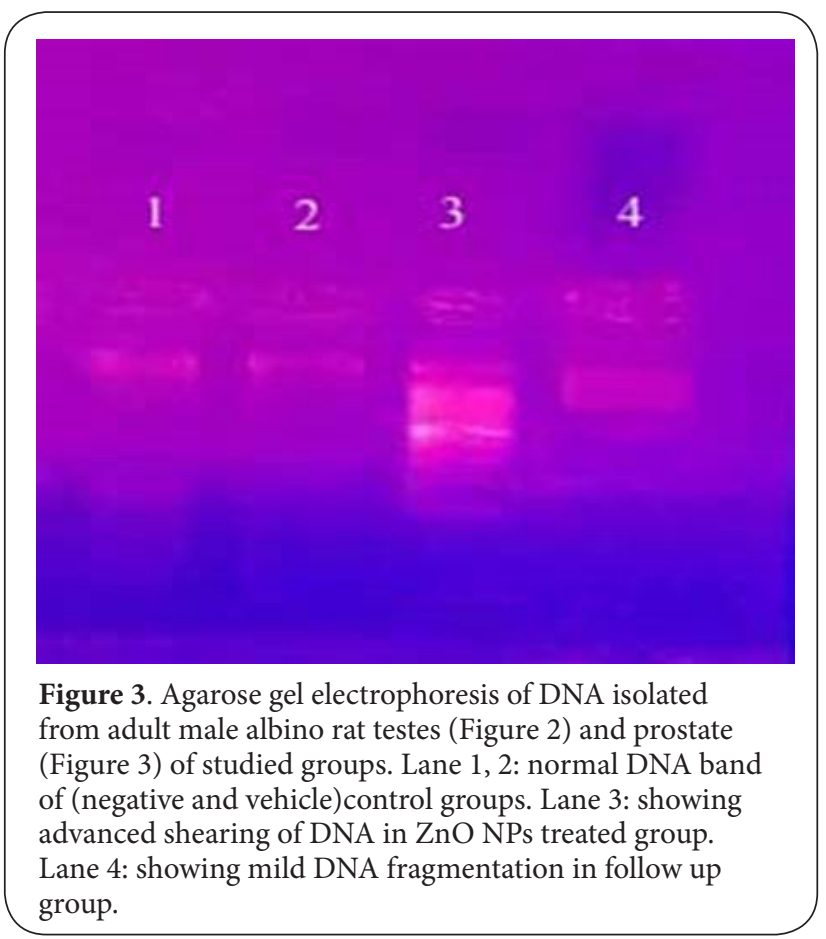

the seminiferous tubules (St) that were lined by germinal epithelium. Little interstitiumcontaining clusters of interstitial cells was also detected between the St (Figure 4a). Group II 
testicular sections showed the covering tunica albuginea with congested sub-capsular blood vessels. Some St were appeared with disorganized and separated germinal epithelium from their basallaminae. Acidophilic vacuolated hyaline material was also detected in the interstitium (Figure 4b). Some sections of St in the same group showed marked cellular loss and absence of sperms in most of them. Some germ cells had dark pyknotic nuclei (Figure 4c). St in the (recovery) group were lined by germinal epithelium. Some germ cells appeared with dark pyknotic nuclei. Interstitium containing almost normal clusters of interstitial cells was also detected (Figure 4d).

Masson trichrome stained sections of the control group showed minimal collagen fibers in the interstitial tissue inbetween St (Figure 5a). Increased collagen fibers in the interstitium around blood vesselsin the treated group (Figure $\mathbf{5 b}$ ) that markedly decreased in the follow up group (Figure 5c).

\section{Immunohistochemical results}

Examination of testicular sections of control group stained with anti-iNos antibody revealed week positive immunoreaction in the cytoplasm of germinal cells lining the seminiferous tubules (Figure 6a). Testicular Sections of group II revealed strong positive immunoreaction in the cytoplasm of germinal

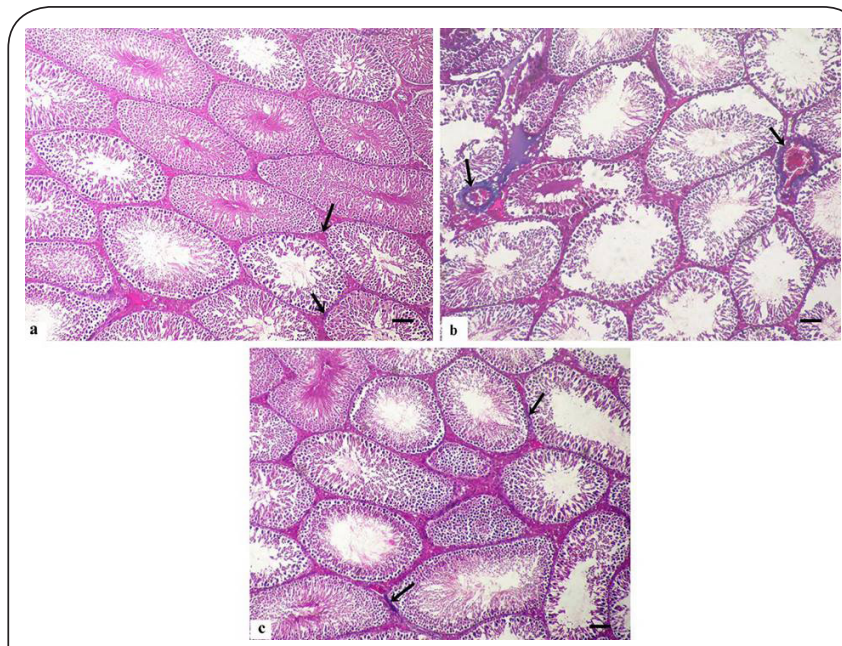

Figure 5. a: Masson trichrome stained sections of the control testis showing minimal collagen fibres (arrow) in the interstitial tissue in-between St.

b: Increased collagen fibres (arrow) in the interstitium around blood vesselsof the treated group.

c: Collagen fibres are markedly decreased (arrow) in the follow up group (Masson trichrome $\times 100$, Scale bar; $50 \mu \mathrm{m}$ ).

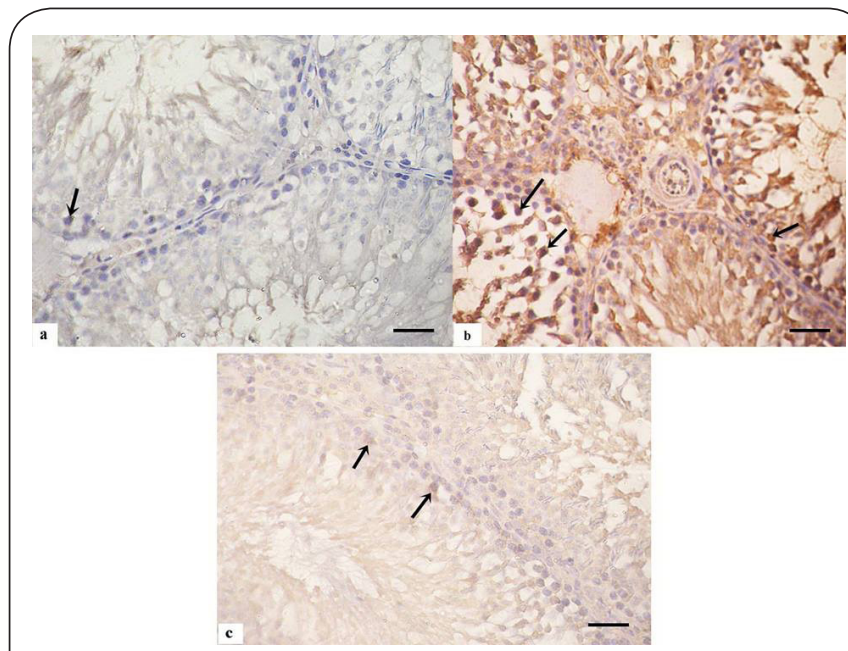

Figure 6. a: Testicular sections of the control group stained with anti-iNos antibody reveal week positive immunoreaction (arrow) in the cytoplasm of few germinal cells lining the seminiferous tubules.

b: Testicular Sections of group II showing strong positive immunoreaction (arrow) in the cytoplasm of germinal epithelial cells.

c: The follow up group showing positive immunoreaction in the cytoplasm of some germinal epithelial cells(arrow) (Immunoperoxidase technique $\times 40$, Scale bar; $20 \mu \mathrm{m}$ ).

epithelial cells (Figure 6b), however, in the follow up group, positive immunoreaction in the cytoplasm of some germinal epithelial cells were detected in the $6^{\text {th }}$ week (Figure $6 c$ ). 


\section{Prostate}

\section{Histological findings}

$\mathrm{H} \& \mathrm{E}-$ stained prostate sections of the control group showed acini lined by columnar epithelium and were separated by thin stroma with oesinophilic homogenous secretions in their lumen (Figure 7a). Prostate of groupll showed pseudostratification of acinar lining epithelium in some areas. Acinar cells with dark pyknotic nuclei were detected, the acinar secretion showed vaculation and stroma appeared widened (Figure 7b) with inflammatory cellular infiltrations (Figure 7c). Acidophilic vacuolated material was revealed in the stroma of the same group in between acini with congested capillary and scattered cells. Acinar cells with dark pyknotic nuclei and vaculated cytoplasm were detected (Figure 7d). Sections in the prostate offollow up group (at the $6^{\text {th }}$ week) showed reduced epithelial height of prostatic acini revert to simple columnar form with area of flattened acinar cells was observed with oesinophilic homogenous secretions in their lumen and separated by thin stroma (Figure 7e).

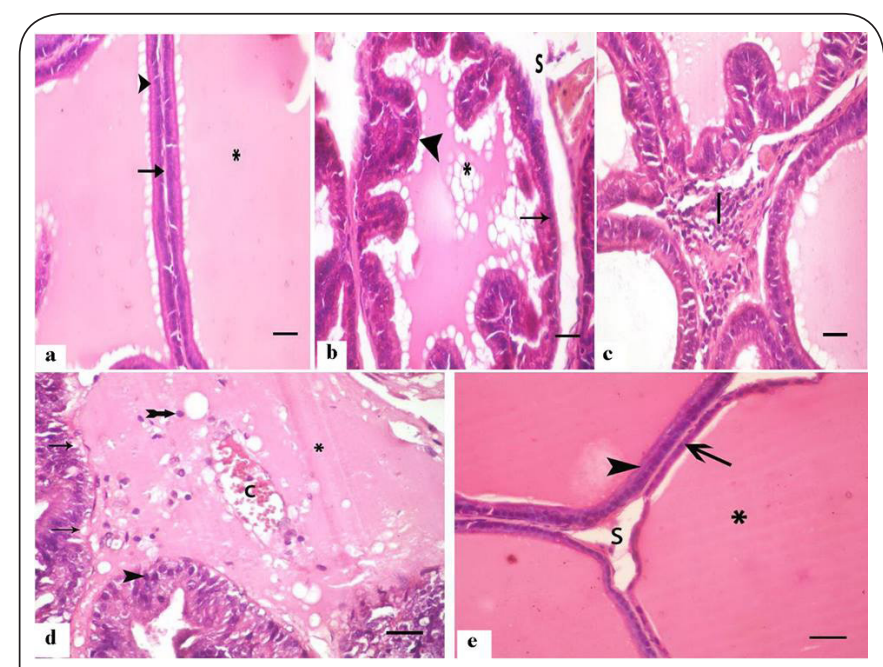

Figure 7. a: H\&E stained sections of prostate of control group showing, acini lined by columnar epithelium (arrow head) and are separated by thin stroma (arrow) with oesinophilic homogenous secretions in their lumen $\left(^{*}\right)$.

b: Prostate of group II showing pseudostratification of acinar lining epithelium (arrow head) in some areas. Acinar cells with dark pyknotic nuclei (arrow) are detected, widened stroma (S) and Vacuolation in the acinar secretion are seen $\left(^{*}\right)$. c: Stroma of the same groupshowing presence of inflammatory cellular infiltrations (I).

d: Acidophilic vacuolated material $\left(^{*}\right)$ is detected in the stroma in the stroma of the same group in between acini with congested capillary (c) and scattered cells(tailed arrow). Acinar cells with dark pyknotic nuclei (arrow head) and vacuolated cytoplasm (arrow) are detected.

e: Sections in the prostate of the follow up group showing reduced epithelial height of prostatic acini revert to simple columnar form (arrow head) with area of flattened acinar cells is observed (arrow) with oesinophilic homogenous secretions in their lumen $\left({ }^{*}\right)$, separated by thin stroma (s) (H\&E $\times 400$, Scale bar; $20 \mu \mathrm{m}$ ).
Masson trichrome stained sections of prostate of the control group showed few blue stained collagen fibres in a narrow stroma in between acini (Figure 8a). Marked increase in the collagen fibers was seen in the widened stroma in between prostatic acini in ZnO NP-treated group (Figure 8b). Marked decrease in the amount of collagen fibers was observed in the follow up group after ZnO NP cessation (Figure 8c).

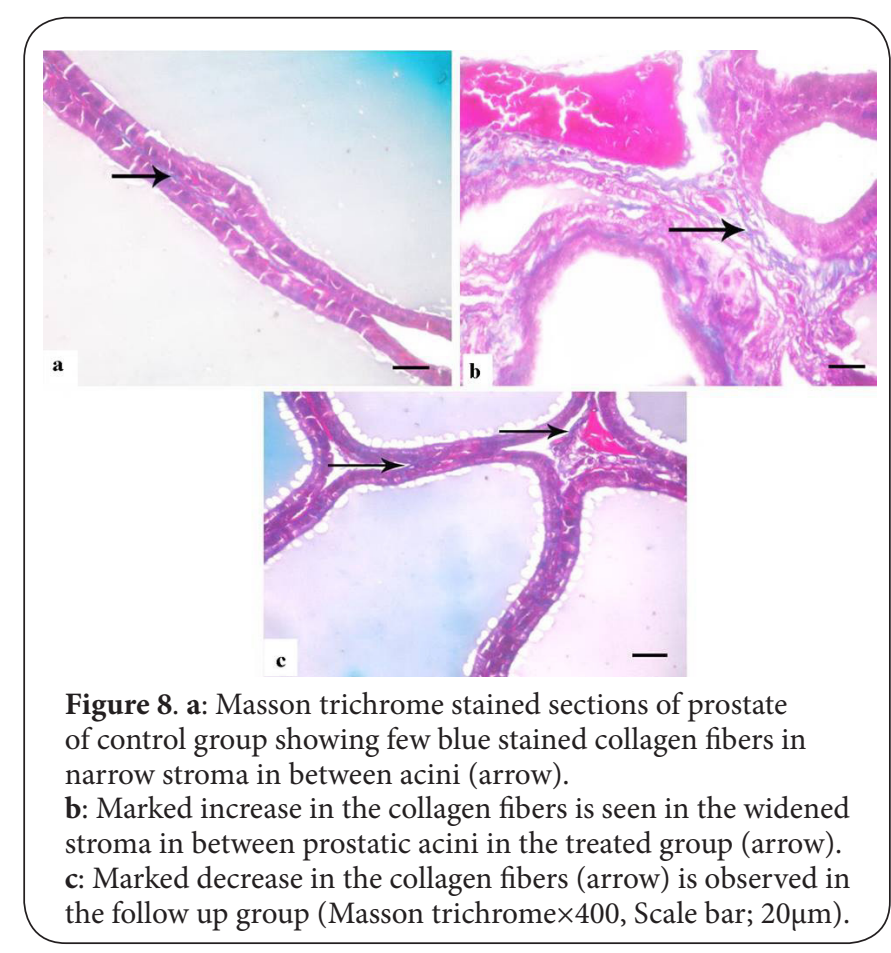

\section{Immunohistochemical results}

Examination of the prostatic stainedsections of the control group with anti-iNos antibody revealed week positive immunoreaction in the cytoplasm of few epithelial cells lining the acini (Figure 9a), while prostatic sections of group II revealed strong positive immunoreaction in the cytoplasm of many epithelial cells lining the acini (Figure 9b). Prostatic sections of the follow up group revealed positive immunoreaction in the cytoplasm of some epithelial cells lining the acini (Figure 9c).

\section{Histomorphometrical Statistical Results}

Statistically significant increase in the mean area percentage of collagen fibers was detected in group II as compared to the control and the follow up groups. No statistically significant difference was detected between control and follow up groups (Table 3). As well, highly statistically significant increase in the percentage of mean area of iNos immunoreaction was noticed in group II as compared to the control and the follow up groups. No statistically significant difference was detected between control and follow up groups (Table 3).

\section{Discussion}

The small size ofNPs increases the possibility for them to 
Table 3. The mean area \% of Masson trichrome and iNos immunoreaction in both testic-ular and prostatic tissues of the studied groups.

\begin{tabular}{c|l|l|l|l|l|l}
\hline \multicolumn{1}{c|}{ Groups } & \multicolumn{2}{|c|}{$\begin{array}{c}\text { Control } \\
\text { (I) }\end{array}$} & \multicolumn{2}{|c|}{$\begin{array}{c}\text { ZnO NP } \\
\text { (II) }\end{array}$} & \multicolumn{2}{c}{$\begin{array}{c}\text { Follow up } \\
\text { (III) }\end{array}$} \\
\hline Parameters & Testis & Prostate & Testis & Prostate & Testis & Prostate \\
\hline Area \% of Masson trichrome & $0.23 \pm 0.06$ & $0.35 \pm 0.01$ & $0.91 \pm 0.12^{*}$ & $0.89 \pm 0.18^{*}$ & $0.26 \pm 0.11$ & $0.36 \pm 0.06$ \\
\hline Area \% of iNos immunoreaction & $20.35 \pm 1.55$ & $23.041 \pm 0.47$ & $64.339 \pm 2.04^{* *}$ & $72.28 \pm 1.01 * *$ & $25.11 \pm 1.62$ & $26.15 \pm 2.01$ \\
\hline \hline
\end{tabular}

Results values are expressed as mean $\pm(\mathrm{SD})$ of $\mathrm{n}=10$ rats/group

${ }^{*}$ Significant as compared with the control and recovery groups, $\mathrm{P}<0.05$

${ }^{\star *}$ Highly significant as compared with the control and recovery groups, $\mathrm{P}<0.001$

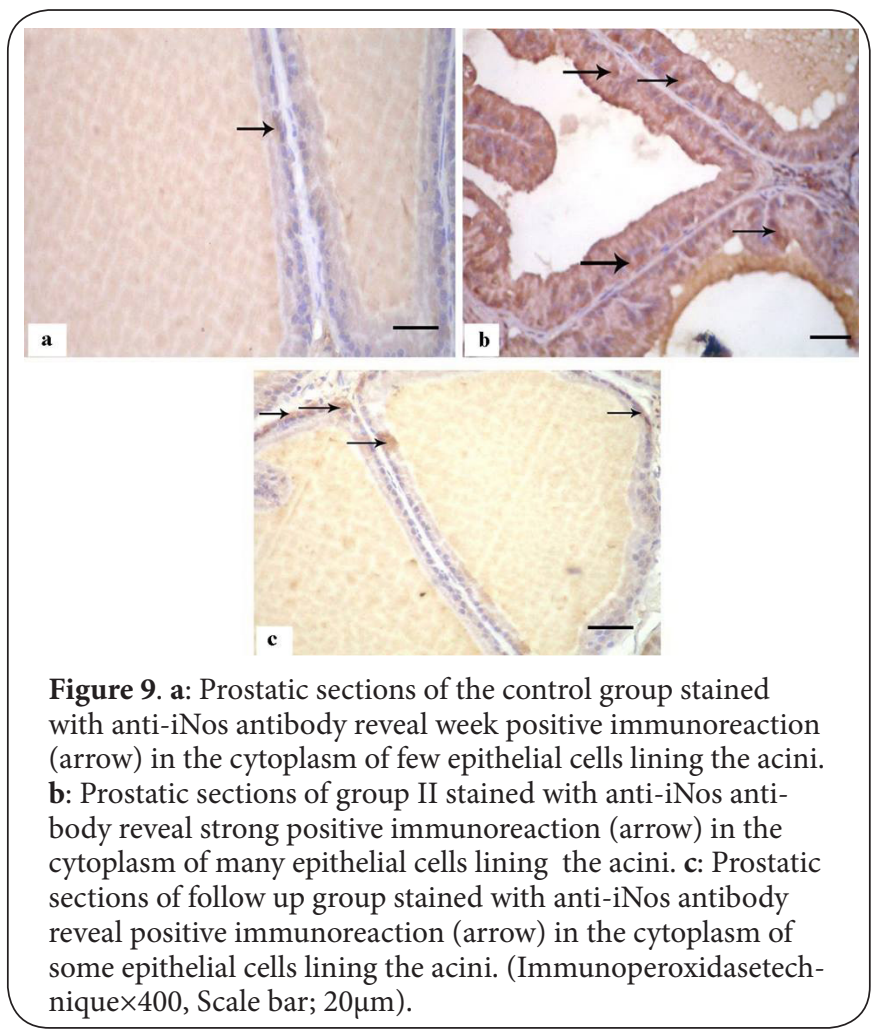

enter the organisms and cells without being trapped under the defense mechanisms of human body (e.g. skin, mucosa, pulmonary epithelium, macrophages, etc) [25]. ZnO NP was confirmed to have selective cytotoxic action on rapidly proliferating cells, whether benign or malignant [26]. The tissue structure, biochemical changes, the body and organ weights are the determinant factors for evaluation of nanoparticle toxicity [27].

In this study, we investigated theZnONPs toxic effects on both testicular and prostatic tissues. Adult albino rats were selected because they are appropriate for studying reproduc- tive toxicity with relatively long life span and they are easily handled [28]. Significant increase of the oxidative stress biomarker MDA with significant reduction in components of the cellular antioxidant system (GSH, SOD, and CAT) were found reflecting increased production of reactive oxygen species (ROS) with its subsequent inflammatory and cytotoxic events.

Ahamed etal. [29] found that Zinc oxide nanoparticles treatment more than $50 \mathrm{mg} / \mathrm{kg}$ body weight induced significant oxidative stress in rats that was proved by significant increased serum level of MDA in the group treated with ZnO NPs.

Several studies similarly showed reduced activities of the antioxidant enzymes, including SOD, CAT and non-enzymatic antioxidant reduced GSH content, furthermore increased level of lipid peroxidation on exposure to ZO NPs [30,31]. The smaller the nanoparticles, the higher the ROS production and the more marked inflammatory response with induction of apoptosis [32-35]. In addition, they were more intoxicating at inducing DNA damage [36].

It was found that in vitro exposure to ZnO NPs significantly increased ROS generation in mouse embryo fibroblast cells [37], in addition to in TM-4 cells and GC2-spd cells [38] compared to the control group, this was reflected by a significant glutathione depletion, increased MDA production, and SO Dinhibition indicative of that oxidative stress may be a key route in inducing the cytotoxicity. Additionally, exposure to $\mathrm{CeO} 2$ nanoparticles also significantly increased the production of MDA, and significantly decreased the activity of SOD and CAT [39].

ROS overproduction with oxidative stress are the most common effects resulting from NPs and cell interaction and are the major mechanism of toxicity [15]. Macrophages or neutrophil activation (to recognize nanoparticles as potential threat) and mitochondrial disruption are strongly related to ROS outburst [25]. Downstream events of ROS consist of membrane damage, DNA damage, and inflammatory response that induces cell death [40].

Elevated levels of TNF- $a$ and decreased the anti-inflam- 
matory IL-4 contents in testicular and prostatic tissues are additional evidences of the aggressive cellular inflammatory response to $\mathrm{ZnO}$ NP exposure through the current study. Such in vivo increased TNF- $a$ in nanoparticle exposure is in accordance with [41-43]. Increased TNF-a, decreased IL-4 and disturbed levels of other inflammation modulatory cytokines on exposure to nanoparticles was reported also by $[42,44]$.

Moreover, in vitro increased TNF- a due to nanoparticle exposure was also detected as $[38,45,46]$. Wu et al. [47] found that $12 \mathrm{~h}$ after high concentrations of ZnO NPs exposure, the levels of IL- 8 and IL-1b protein were significantly increased in vitro cell model mostly affecting the inflammatory response. All findings are supportive of the inflammatory and immunomodulatory response induced by $\mathrm{ZnO}$ NP and other structurally related nanoparticles.

In the present study there was a significant increase of both laddered and sheared DNA fragments in ZnO NPs treated group compared to control groups and the follow up (recovery) group confirmed qualitatively by gel electrophoresis of DNA extracted from testicular and prostatic tissues. These results were in cope with [48-51] who found that ZnO NPs caused DNA damage and apoptotic changes and also evidenced the formation of both laddered and sheared DNA on an agarose gel.

Furthermore, membrane injury, inflammatory response, DNA damage and apoptosis were induced by ZnO NPs exposure in vitro as demonstrated in studies done by $[37,52]$. In addition to the increased DNA damage, the decreased DNA repair capacity in cells exposed to ZnO NPs, with the cell cycle arrest were found to contribute to the genotoxicity of cells [38].

DNA fragmentation assay is the most reliable method for detection of apoptotic cells [53]. Several studies used it to detect the toxicity of NPs by assessing DNA strand shearing [54].

Due to the small size, ZnO NPs are capable of reaching the nucleus and inducing direct chemical interaction with DNA causes generation of ROS that further damage DNA and speeding up the apoptotic process by formation of oxidationinduced DNA adducts [33,55-57]. Additionally, upregulation of inflammatory cytokines triggers activation of transcription factors that bind to DNA elements and stimulate DNA damage [58].

DNA damage and cellular apoptosis, can also be related to the stimulation of the mitogen activated protein kinase (MAPK) pathways which are important mediators of signal transduction and play major role in regulating many cellular processes [39,59].

Histopathological assessment of testes of ZnO NPs-treated group revealed the covering tunica albuginea with congested sub-capsular blood vessels. Some semineferous tubules appeared with disorganized and germinal epithelium wereseparated from their basement membranes. Acidophilic vacuolated hyaline material was detected in the interstitium. Other sections of St in ZnO NPs treated group revealed marked cellular loss and absence of sperms in most of them. Some germ cells had dark pyknotic nuclei. Actively proliferating cells were previously reported to be more prone to certain drugs than quiescent cells. The same might occur from interactions between such cells and ZnO NPs as they tend to take in more nutrients from their surroundings and in turn absorb more $\mathrm{ZnO}$ NPs. Accumulated ZnO NPs in the cells elevated intracellular ROS expression inconspicuously, induced acute inflammatory response, significantly decreased the DNA amounts [47].

Masson trichrome stained sections showed statistically significant increase in the mean area percent of collagen fibers in group II as compared to the control and the follow up groups. Immunohistochemical examination of testicular sections of group II revealed highly statistically significant increase in the mean area percent of iNOs immunoreaction as compared to the control and the follow up groups.Nanoparticles easily pass through the blood-brain, and blood-testis barriers [9]. Similar to our results, treatment with small amounts of nanoparticles can induce toxic effects on germ cells and decrease in sperm quality $[7,8]$. ZnO NPs induce testicular damage in a dose dependent manner in mice as well where the pathological results were in the form of epithelial vacuolation, sloughing and detachment of germ cells, and disorganization of germ cell layers $[60,61]$.

Similar testicular and reproductive effects of zinc oxide nanoparticles were also detected on male Japanese quail [62]. Guo et al. [63] also reported that high doses of nanosized titanium dioxide caused reduced sperm density and motility, increased sperm abnormality and apoptosis in ICR mice. Park et al. [16], Kim et al. [5] tested the effects of different doses of $100 \mathrm{~nm}$ ZnONP on adult rats and found out acinar cell apoptosis and chronic inflammation on pathological examination of parenchymatous organs with a dose of $500 \mathrm{mg} / \mathrm{kg} /$ day (very close to that used in our study). Similar to our study, after a two-week recovery period,the observed lesions significantly improved in the recovery group due to the interruption of test-article administration. Comparable improvement in pathological findings two weeks after cessation of $\mathrm{ZnO} N \mathrm{~N}$ administration was also proved by [64].

Previous authors described similar histopathological features in parenchymatous organs; like liver and kidney, of rats treated with zinc oxide nanoparticles [65]. Komatsu et al. [66] showed that in vitro testicular cell testing evaluation revealed also similar results, $\mathrm{TiO}_{2}$ and carbon black (CB) was toxic to mouse Leydig TM3 cells. Asare et al. [67] found that silver nanoparticles were toxic on testicular embryonic carcinoma cell line, and primary testicular cell from mice. Sertoli cell lines and the spermatocyte cell lineswere used inmice by Liu et al. [38] to investigate the reproductive effects of ZnO NPs at the sublethal dose and found compromised the integrity of the blood-testis barrier by down-regulation of the expression of specific proteins with impaired spermatogenesis.

The presence of Sertoli cell cytoplasmic vacuoles indicated direct harm of nanoparticles on these cells. These lesions are early signs of testicular injury and are considered as the main Sertoli cell response to xenobiotics $[\mathbf{6 8 , 6 9}]$. Attacked Sertoli 
cells caused multinucleated giant cell formation derived mainly from clumped spermatogenic cells that had lost their contact with Sertoli cells [70]. These particles also indirectly led to hormonal imbalance by decreased Sertoli cells population and the consequent impairment in spermatogenesis [71].

Another possibility is that ZnO NPs may affect Leydig cells and inhibit testosterone synthesis; nanoparticles were taken by mouse Leydig cells and affected their viability and gene expression [66]. Talebi et al. [60] also reported that the Leydig cell numbers were significantly decreased in ZnO NP-treated groups.

Additionally, reduction of daily number of sperms seems to be associated with the reduction in the number of spermatids and spermatogonia cells [72]. This reduction in the morphometrical parameters may have been a consequence of the apoptotic effects of ZnO NPs on spermatogenic cells $[60,73]$. NPsnot only can induce apoptosis but some NPs types have been recognized as a novel class of autophagy activators and inducers of autophagic cell death also [74].

Histopathological examination of prostate of group II showed pseudostratification of acinar lining epithelium in some areas where Acinar cells were with dark pyknotic nuclei, the vaculated acinar secretion and widened stroma were detected with inflammatory cellular infiltrations and congested capillary. There are very limited experiments in literature examining prostate; for example, similar significant pathological lesions of epithelial hyperplasia and vacuolation, intracytoplasmic hyaline droplet, submucosal and stromal edema and inflammation, eosinophilic chief cell, and mucous cell hyperplasia in glandular tissues of the stomach, pancreas, eye, and prostate gland were observed with the $500 \mathrm{mg} / \mathrm{kg}$ administration regimen of ZnO NPs where suppurative inflammation in the prostate gland was also observed. These effects were speculated to be due to continuous irritation of exposed cell with the oxidative stress leading to DNA damage and apoptosis [5].

Both Masson trichrome and immunohistochemical staining revealed statistically significant increase in the mean area percent of collagen fibers and increase in the mean area percent of iNOs in group II as compared to the control and the follow up groups respectively. As well, Khan et al. [75] reported previousely that a two-generation reproductive toxicity study of $\mathrm{ZnCl} 2$ in rats showed the reduction of prostate weight and induction of reproductive tract lesions. Wang et al. [76] suggested that the toxicity of $\mathrm{ZnO}$ nanoparticles may increase from $\mathrm{Zn}$ ions diffusion of particles and their direct contact with organs. Therefore, gonadal and reproductive toxicity of such particles are of special concern and still in need of further exploration.

\section{Conclusion and recommendations}

$\mathrm{ZnO}$ nanoparticles cause several deleterious effects to male reproductive organs. Therefore, it is critical to understand their nature and origin of toxicity. Limiting exposure to such materials has great impact on controlling their toxic profile.
Yet, the scientific community should dedicate attention to establish and validate well designed protocols for toxicity examination, in order to accurately determine the potential threats of NPs applications mainly on reproductive organs.

\section{Competing interests}

The authors declare that they have no competing interests.

Authors' contributions

\begin{tabular}{|l|c|c|c|c|}
\hline Authors' contributions & DIAM & RHD & SMA & SMA \\
\hline Research concept and design & $\checkmark$ & $\checkmark$ & $\checkmark$ & $\checkmark$ \\
\hline Collection and/or assembly of data & $\checkmark$ & $\checkmark$ & $\checkmark$ & $\checkmark$ \\
\hline Data analysis and interpretation & $\checkmark$ & $\checkmark$ & $\checkmark$ & $\checkmark$ \\
\hline Writing the article & $\checkmark$ & $\checkmark$ & $\checkmark$ & $\checkmark$ \\
\hline Critical revision of the article & $\checkmark$ & $\checkmark$ & $\checkmark$ & $\checkmark$ \\
\hline Final approval of article & $\checkmark$ & $\checkmark$ & $\checkmark$ & $\checkmark$ \\
\hline Statistical analysis & $\checkmark$ & $\checkmark$ & $\checkmark$ & $\checkmark$ \\
\hline
\end{tabular}

Publication history

Editor: Giuseppe Musumeci, University of Catania, Italy. Received: 29-Apr-2019 Final Revised: 09-Jun-2019

Accepted: 13-Jun-2019 Published: 14-Jul-2019

\section{References}

1. Ghosh M, Sinha S, Jothiramajayam M, Jana A, Nag A and Mukherjee A. Cyto-genotoxicity and oxidative stress induced by zinc oxide nanoparticle in human lymphocyte cells in vitro and Swiss albino male mice in vivo. Food Chem Toxicol. 2016; 97:286-296. | Article | PubMed

2. Almansour MI, Alferah MA, Shraideh ZA and Jarrar BM. Zinc oxide nanoparticles hepatotoxicity: Histological and histochemical study. Environ Toxicol Pharmacol. 2017; 51:124-130. | Article | PubMed

3. Radad K, Al-Shraim M, Moldzio R and Rausch WD. Recent advances in benefits and hazards of engineered nanoparticles. Environ Toxicol Pharmacol. 2012; 34:661-72. | Article | PubMed

4. Khlebtsov $\mathrm{N}$ and Dykman L. Biodistribution and toxicity of engineered gold nanoparticles: a review of in vitro and in vivo studies. Chem Soc Rev. 2011; 40:1647-71. | Article | PubMed

5. Kim YR, Park JI, Lee EJ, Park SH, Seong NW, Kim JH, Kim GY, Meang EH, Hong JS, Kim SH, Koh SB, Kim MS, Kim CS, Kim SK, Son SW, Seo YR, Kang BH, Han BS, An SS, Yun HI and Kim MK. Toxicity of 100 nm zinc oxide nanoparticles: a report of 90-day repeated oral administration in Sprague Dawley rats. Int J Nanomedicine. 2014; 9 Suppl 2:109-26. Article | PubMed Abstract | PubMed FullText

6. de Franca LR, Ghosh S, Ye SJ and Russell LD. Surface and surfaceto-volume relationships of the Sertoli cell during the cycle of the seminiferous epithelium in the rat. Biol Reprod. 1993; 49:1215-28. | Article | PubMed

7. Braydich-Stolle LK, Lucas B, Schrand A, Murdock RC, Lee T, Schlager JJ, Hussain SM and Hofmann MC. Silver nanoparticles disrupt GDNF/Fyn kinase signaling in spermatogonial stem cells. Toxicol Sci. 2010; 116:57789. | Article | PubMed Abstract | PubMed FullText

8. Gromadzka-Ostrowska J, Dziendzikowska K, Lankoff A, Dobrzynska M, Instanes C, Brunborg G, Gajowik A, Radzikowska J, Wojewodzka M and Kruszewski M. Silver nanoparticles effects on epididymal sperm in rats. Toxicol Lett. 2012; 214:251-8. | Article I PubMed

9. Borm PJ and Kreyling W. Toxicological hazards of inhaled nanoparticles-potential implications for drug delivery. J Nanosci Nanotechnol. 2004; 4:521-31. | PubMed

10. Bedwal RS and Bahuguna A. Zinc, copper and selenium in reproduction. Experientia. 1994; 50:626-40. | Article | PubMed

11. Croxford TP, McCormick NH and Kelleher SL. Moderate zinc deficiency reduces testicular Zip6 and Zip10 abundance and impairs 
spermatogenesis in mice. J Nutr. 2011; 141:359-65. | Article | PubMed Abstract | PubMed FullText

12. Tsuji JS, Maynard AD, Howard PC, James JT, Lam CW, Warheit DB and Santamaria AB. Research strategies for safety evaluation of nanomaterials, part IV: risk assessment of nanoparticles. Toxicol Sci. 2006; 89:42-50. | Article | PubMed

13. Moller P, Jacobsen NR, Folkmann JK, Danielsen PH, Mikkelsen $L$, Hemmingsen JG, Vesterdal LK, Forchhammer L, Wallin H and Loft S. Role of oxidative damage in toxicity of particulates. Free Radic Res. 2010; 44:1-46. | Article | PubMed

14. Institute of Laboratory Animal Resources, Commission on Life Sciences, National Research Council. Guide for the Care and Use of Laboratory Animals. 8th ed. National Academy Press, Washington DC. 2011; 21-55. I Website

15. Sharma V, Anderson D and Dhawan A. Zinc oxide nanoparticles induce oxidative DNA damage and ROS-triggered mitochondria mediated apoptosis in human liver cells (HepG2). Apoptosis. 2012; 17:852-70. | Article I PubMed

16. Park HS, Kim SJ, Lee TJ, Kim GY, Meang E, Hong JS, Kim SH, Koh SB, Hong SG, Sun YS, Kang JS, Kim YR, Kim MK, Jeong J, Lee JK, Son WC and Park JH. A 90-day study of sub-chronic oral toxicity of $20 \mathrm{~nm}$ positively charged zinc oxide nanoparticles in Sprague Dawley rats. Int I Nanomedicine. 2014; 9 Suppl 2:93-107. | Article | PubMed Abstract | PubMed FullText

17. Parasuraman $S$, Raveendran $R$ and Kesavan R. Blood sample collection in small laboratory animals. J Pharmacol Pharmacother. 2010; 1:87-93. | Article | PubMed Abstract | PubMed FullText

18. Ohkawa $\mathrm{H}$, Ohishi $\mathrm{N}$ and Yagi $\mathrm{K}$. Assay for lipid peroxides in animal tissues by thiobarbituric acid reaction. Anal Biochem. 1979; 95:351-8. | Article I PubMed

19. Oberley LW and Spitz DR. Nitroblue tetrazolium. In: Greenwald, RA (ed). Handbook of Methods for Oxygen Radical Research, CRC Press Boca Raton, Florida. 1985; 217-220.

20. Das K, Samanta L and Chainy G. A modified spectrophotometric assay of superoxide dismutase using nitrite formation by superoxide radicals. Indian Journal of Biochemistry and Biophysics. 2000; 37:201-204.

21. Beutler $B$ and Cerami A. Cachectin: more than a tumor necrosis factor. $N$ Engl J Med. 1987; 316:379-85. | Article | PubMed

22. Sellins KS and Cohen JJ. Gene induction by gamma-irradiation leads to DNA fragmentation in lymphocytes. J Immunol. 1987; 139:3199-206. | Article | PubMed

23. Bancroft J and Gamble A. Theory and Practice of Histological Techniques, 6th ed. Churchill Livingstone, New York, London. 2008; 165-175.

24. Ramos-Vara JA, Kiupel M, Baszler T, Bliven L, Brodersen B, Chelack B, Czub S, Del Piero F, Dial S, Ehrhart EJ, Graham T, Manning L, Paulsen D, Valli VE and West K. Suggested guidelines for immunohistochemical techniques in veterinary diagnostic laboratories. J Vet Diagn Invest. 2008; 20:393-413. | Article | PubMed

25. Vlastou E, Gazouli M, Ploussi A, Platoni K and Efstathopoulos EP. Nanoparticles: nanotoxicity aspects. In Journal of Physics: Conference Series IOP Publishing. 2017; 931:012020.

26. Taccola L, Raffa V, Riggio C, Vittorio O, lorio MC, Vanacore R, Pietrabissa $A$ and Cuschieri A. Zinc oxide nanoparticles as selective killers of proliferating cells. Int J Nanomedicine. 2011; 6:1129-40. | Article | PubMed Abstract | PubMed FullText

27. Wang C, Lu J, Zhou L, Li J, Xu J, Li W, Zhang L, Zhong X and Wang T. Effects of Long-Term Exposure to Zinc Oxide Nanoparticles on Development, Zinc Metabolism and Biodistribution of Minerals ( $\mathrm{Zn}, \mathrm{Fe}, \mathrm{Cu}, \mathrm{Mn})$ in Mice. PLoS One. 2016; 11:e0164434. | Article | PubMed Abstract | PubMed FullText

28. Hegazy AA, Elsayed NE, Ahmad MM and Omar NM. Effect of Formaldehyde on Rat Testis Structure. Academia Anatomica International. 2017; 3:15-23.

29. Ahamed M, Akhtar MJ, Raja M, Ahmad I, Siddiqui MK, AlSalhi MS and Alrokayan SA. ZnO nanorod-induced apoptosis in human alveolar adenocarcinoma cells via $\mathrm{p} 53$, survivin and bax/bcl-2 pathways: role of oxidative stress. Nanomedicine. 2011; 7:904-13. | Article | PubMed

30. Hao $L$ and Chen $L$. Oxidative stress responses in different organs of carp (Cyprinus carpio) with exposure to $\mathrm{ZnO}$ nanoparticles. Ecotoxicol Environ Saf. 2012; 80:103-10. | Article | PubMed

31. AL-Hamdani SATA. Pathological study of lethal concentration of N-ZNO in common carp Cyprinus Carpio L. Basrah Journal of Veterinary Research. 2013; 12:200-207.

32. Kaewamatawong T, Kawamura N, Okajima M, Sawada M, Morita T and Shimada A. Acute pulmonary toxicity caused by exposure to colloidal silica: particle size dependent pathological changes in mice. Toxicol Pathol. 2005; 33:743-9. | Article | PubMed

33. Karlsson HL, Cronholm P, Gustafsson J and Moller L. Copper oxide nanoparticles are highly toxic: a comparison between metal oxide nanoparticles and carbon nanotubes. Chem Res Toxicol. 2008; 21:172632. | Article | PubMed

34. Kim KT, Klaine SJ, Cho J, Kim SH and Kim SD. Oxidative stress responses of Daphnia magna exposed to TiO2 nanoparticles according to size fraction. Science of the Total Environment. 2010; 408:2268-2272.

35. Park J, Lim DH, Lim HJ, Kwon T, Choi JS, Jeong S, Choi IH and Cheon J. Size dependent macrophage responses and toxicological effects of Ag nanoparticles. Chem Commun (Camb). 2011; 47:4382-4. | Article | PubMed

36. Midander K, Cronholm P, Karlsson HL, Elihn K, Moller L, Leygraf C and Wallinder IO. Surface characteristics, copper release, and toxicity of nano- and micrometer-sized copper and copper(II) oxide particles: a cross-disciplinary study. Small. 2009; 5:389-99. | Article | PubMed

37. Yang $\mathrm{H}$, Liu C, Yang D, Zhang $\mathrm{H}$ and Xi Z. Comparative study of cytotoxicity, oxidative stress and genotoxicity induced by four typical nanomaterials: the role of particle size, shape and composition. J Appl Toxicol. 2009; 29:69-78. | Article | PubMed

38. Liu Q, Xu C, Ji G, Liu H, Mo Y, Tollerud DJ, Gu A and Zhang Q. Sublethal effects of zinc oxide nanoparticles on male reproductive cells. Toxicol In Vitro. 2016; 35:131-8. | Article | PubMed

39. Cheng G, Guo W, Han L, Chen E, Kong L, Wang L, Ai W, Song N, Li H and Chen $\mathrm{H}$. Cerium oxide nanoparticles induce cytotoxicity in human hepatoma SMMC-7721 cells via oxidative stress and the activation of MAPK signaling pathways. Toxicol In Vitro. 2013; 27:1082-8. | Article | PubMed

40. Setyawati MI, Yuan X, Xie J and Leong DT. The influence of lysosomal stability of silver nanomaterials on their toxicity to human cells. Biomaterials. 2014; 35:6707-15. | Article | PubMed

41. Tin Tin Win S, Mitsushima D, Yamamoto S, Fukushima A, Funabashi T, Kobayashi $T$ and Fujimaki H. Changes in neurotransmitter levels and proinflammatory cytokine mRNA expressions in the mice olfactory bulb following nanoparticle exposure. Toxicol Appl Pharmacol. 2008; 226:192-8. | Article | PubMed

42. Gui S, Zhang Z, Zheng L, Cui Y, Liu X, Li N, Sang X, Sun Q, Gao G, Cheng Z, Cheng J, Wang L, Tang M and Hong F. Molecular mechanism of kidney injury of mice caused by exposure to titanium dioxide nanoparticles. $J$ Hazard Mater. 2011; 195:365-70. | Article | PubMed

43. Khan HA, Abdelhalim MA, Alhomida AS and Al Ayed MS. Transient increase in IL-1beta, IL-6 and TNF-alpha gene expression in rat liver exposed to gold nanoparticles. Genet Mol Res. 2013; 12:5851-7. | Article I PubMed

44. Cui Y, Liu H, Zhou M, Duan Y, Li N, Gong X, Hu R, Hong M and Hong F. Signaling pathway of inflammatory responses in the mouse liver caused by TiO2 nanoparticles. J Biomed Mater Res A. 2011; 96:221-9. | Article | PubMed

45. Park EJ, Yi J, Kim Y, Choi K and Park K. Silver nanoparticles induce cytotoxicity by a Trojan-horse type mechanism. Toxicol In Vitro. 2010; 24:872-8. | Article | PubMed

46. Muller L, Riediker M, Wick P, Mohr M, Gehr P and Rothen-Rutishauser B. Oxidative stress and inflammation response after nanoparticle exposure: differences between human lung cell monocultures and an advanced three-dimensional model of the human epithelial airways. $J$ R Soc Interface. 2010; 7 Suppl 1:S27-40. | Article | PubMed Abstract | PubMed FullText 
47. Wu Z, Guan R, Tao M, Lyu F, Cao G and Liu M et al. Assessment of the toxicity and inflammatory effects of different-sized zinc oxide nanoparticles in 2D and 3D cell cultures. RSC Advances. 2017; 7:1243712445.

48. Gojova A, Guo B, Kota RS, Rutledge JC, Kennedy IM and Barakat Al. Induction of inflammation in vascular endothelial cells by metal oxide nanoparticles: effect of particle composition. Environ Health Perspect. 2007; 115:403-9. | Article | PubMed Abstract | PubMed FullText

49. Osman IF, Baumgartner A, Cemeli E, Fletcher JN and Anderson D. Genotoxicity and cytotoxicity of zinc oxide and titanium dioxide in HEp2 cells. Nanomedicine (Lond). 2010; 5:1193-203. I Article I PubMed

50. Alarifi S, Ali D, Al-Doaiss AA, Ali BA, Ahmed $\mathrm{M}$ and Al-Khedhairy AA. Histologic and apoptotic changes induced by titanium dioxide nanoparticles in the livers of rats. Int J Nanomedicine. 2013; 8:3937-43. | Article | PubMed Abstract | PubMed FullText

51. Baky NA, Faddah LM, Al-Rasheed NM and Fatani AJ. Induction of inflammation, DNA damage and apoptosis in rat heart after oral exposure to zinc oxide nanoparticles and the cardioprotective role of alpha-lipoic acid and vitamin E. Drug Res (Stuttg). 2013; 63:228-36. | Article I PubMed

52. Jeng HA and Swanson J. Toxicity of metal oxide nanoparticles in mammalian cells. J Environ Sci Health A Tox Hazard Subst Environ Eng. 2006; 41:2699-711. | Article | PubMed

53. Singh N, Manshian B, Jenkins GJ, Griffiths SM, Williams PM, Maffeis TG, Wright CJ and Doak SH. NanoGenotoxicology: the DNA damaging potential of engineered nanomaterials. Biomaterials. 2009; 30:3891914. | Article | PubMed

54. Arora S, Rajwade JM and Paknikar KM. Nanotoxicology and in vitro studies: the need of the hour. Toxicol Appl Pharmacol. 2012; 258:151-65. | Article | PubMed

55. Lin CC, Lin WH and Li YY. Synthesis of ZnO nanowires and their applications as an ultraviolet photodetector. J Nanosci Nanotechnol. 2009; 9:2813-9. | PubMed

56. Cadet J, Douki T and Ravanat JL. Oxidatively generated base damage to cellular DNA. Free Radic Biol Med. 2010; 49:9-21. | Article | PubMed

57. Adjei IM, Sharma B and Labhasetwar V. Nanoparticles: cellular uptake and cytotoxicity. In: Capco D., Chen Y. (eds) Nanomaterial. Advances in Experimental Medicine and Biology. Springer, Dordrecht. 2014; 811:7391.

58. Patel P, Kansara K, Senapati VA, Shanker R, Dhawan A and Kumar A. Cell cycle dependent cellular uptake of zinc oxide nanoparticles in human epidermal cells. Mutagenesis. 2016; 31:481-90. I Article I PubMed

59. Navarro R, Busnadiego I, Ruiz-Larrea MB and Ruiz-Sanz JI. Superoxide anions are involved in doxorubicin-induced ERK activation in hepatocyte cultures. Ann N Y Acad Sci. 2006; 1090:419-28. | Article | PubMed

60. Talebi AR, Khorsandi $L$ and Moridian M. The effect of zinc oxide nanoparticles on mouse spermatogenesis. J Assist Reprod Genet. 2013; 30:1203-9. | Article | PubMed Abstract | PubMed FullText

61. Shrivastava R, Raza S, Yadav A, Kushwaha P and Flora SJ. Effects of subacute exposure to $\mathrm{TiO} 2, \mathrm{ZnO}$ and $\mathrm{Al} 2 \mathrm{O} 3$ nanoparticles on oxidative stress and histological changes in mouse liver and brain. Drug Chem Toxicol. 2014; 37:336-47. | Article | PubMed

62. Khoobbakht Z, Mohammadi M, Mehr MR, Mohammadghasemi F and Sohani MM. Comparative effects of zinc oxide, zinc oxide nanoparticle and zinc-methionine on hatchability and reproductive variables in male Japanese quail. Anim Reprod Sci. 2018; 192:84-90. | Article | PubMed

63. Guo LL, Liu XH, Qin DX, Gao L, Zhang HM, Liu JY and Cui YG. [Effects of nanosized titanium dioxide on the reproductive system of male mice]. Zhonghua Nan Ke Xue. 2009; 15:517-22. I PubMed

64. C A, H KH and Kelmani RC. A Comparative In Vivo Scrutiny of Biosynthesized Copper and Zinc Oxide Nanoparticles by Intraperitoneal and Intravenous Administration Routes in Rats. Nanoscale Res Lett. 2018; 13:93. | Article | PubMed Abstract | PubMed FullText

65. Abbasalipourkabir R, Moradi H, Zarei S, Asadi S, Salehzadeh A, Ghafourikhosroshahi A, Mortazavi M and Ziamajidi N. Toxicity of zinc oxide nanoparticles on adult male Wistar rats. Food Chem Toxicol. 2015; 84:154-60. | Article | PubMed

66. Komatsu T, Tabata M, Kubo-Irie M, Shimizu T, Suzuki K, Nihei Y and Takeda K. The effects of nanoparticles on mouse testis Leydig cells in vitro. Toxicol In Vitro. 2008; 22:1825-31. | Article | PubMed

67. Asare N, Instanes C, Sandberg WJ, Refsnes M, Schwarze P, Kruszewski M and Brunborg G. Cytotoxic and genotoxic effects of silver nanoparticles in testicular cells. Toxicology. 2012; 291:65-72. | Article I PubMed

68. Boekelheide K, Fleming SL, Johnson KJ, Patel SR and Schoenfeld HA. Role of Sertoli cells in injury-associated testicular germ cell apoptosis. Proc Soc Exp Biol Med. 2000; 225:105-15. | Article | PubMed

69. Fiorini C, Tilloy-Ellul A, Chevalier S, Charuel C and Pointis G. Sertoli cell junctional proteins as early targets for different classes of reproductive toxicants. Reprod Toxicol. 2004; 18:413-21. | Article I PubMed

70. Mirhoseini M, Mohamadpour M and Khorsandi L. Toxic effects of Carthamus tinctorius L. (Safflower) extract on mouse spermatogenesis. J Assist Reprod Genet. 2012; 29:457-61. | Article | PubMed Abstract | PubMed FullText

71. Mozaffari Z, Parivar K, Roodbari N and Irani S. Histopathological evaluation of the toxic effects of zinc oxide $(\mathrm{ZnO})$ nanoparticles on testicular tissue of NMRI adult mice. Advanced Studies in Biology. 2015; 7:275-291.

72. Creasy D, Bube A, de Rijk E, Kandori H, Kuwahara M, Masson R, Nolte T, Reams R, Regan K, Rehm S, Rogerson P and Whitney K. Proliferative and nonproliferative lesions of the rat and mouse male reproductive system. Toxicol Pathol. 2012; 40:40S-121S. | Article | PubMed

73. Moffit JS, Bryant BH, Hall SJ and Boekelheide K. Dose-dependent effects of sertoli cell toxicants 2,5-hexanedione, carbendazim, and mono-(2ethylhexyl) phthalate in adult rat testis. Toxicol Pathol. 2007; 35:719-27. | Article | PubMed

74. Zabirnyk O, Yezhelyev M and Seleverstov O. Nanoparticles as a novel class of autophagy activators. Autophagy. 2007; 3:278-81. | Article | PubMed

75. Khan AT, Graham TC, Ogden L, Ali S, Salwa, Thompson SJ, Shireen KF and Mahboob M. A two-generational reproductive toxicity study of zinc in rats. J Environ Sci Health B. 2007; 42:403-15. I Article I PubMed

76. Wang HJ, Growcock AC, Tang TH, O'Hara J, Huang YW and Aronstam RS. Zinc oxide nanoparticle disruption of store-operated calcium entry in a muscarinic receptor signaling pathway. Toxicol In Vitro. 2010; 24:195361. | Article | PubMed

Citation:

Mesallam DIA, Deraz RH, Abdel Aal SM and

Ahmed SM. Toxicity of Subacute Oral Zinc Oxide Nanoparticles on Testes and Prostate of Adult Albino Rats and Role of Recovery. J Histol Histopathol. 2019; 6:2. http://dx.doi.org/10.7243/2055-091X-6-2 